\title{
PENINGKATAN KEMAMPUAN \\ MEMBUAT MEDIA PEMBELAJARAN BAHASA ARAB MENGGUNAKAN APLIKASI \\ "CAMTASIA STUDIO" \\ PADA MAHASISWA PROGRAM STUDI PENDIDIKAN BAHASA ARAB UIN SUNAN AMPEL SURABAYA
}

\author{
Ahmad Fauzi \\ Universitas Islam Negeri Sunan Ampel Surabaya \\ ahmad.fauzi@uinsby.ac.id
}

\begin{abstract}
With the existence of learning media, not only overcoming limitations possessed by teacher in teaching and learning process, but with the existence of learning media created direct interaction between teaching materials and students, that will facilitate students in learning. Therefore, researchers used the camtasia video media as one of the learning media for Arabic that will be developed by students of Sunan Ampel Surabaya State Islamic University in third semester. This study uses the Class Action Research method so that researchers get the maximum value from the media developed by students by using three times of practicum for media improvement. The purpose of this study is to develop technology-based Arabic language learning media, especially multimedia software that is already very familiar with students.
\end{abstract}

Keyword: Learning media, camtasia video, Arabic language, UIN Sunan Ampel Surabaya.

Abstrak: media pembelajaran, bukan hanya mengatasi keterbatasan yang dimiliki oleh pengajar dalam melakukan proses belajar mengajar, tetapi juga, media pembelajaran tercipta sebagai pendung interaksi langsung antara bahan ajar dengan peserta didik yang akan memudahkan peserta didik dalam belajar. Dalam penelitian ini diuraikan tentang penggunaan media camtasia video sebagai salah satu media pembelajaran bahasa Arab yang digunakan oleh mahasiswa Universitas Islam Negeri Sunan Ampel Surabaya semester tigadalam mengambangkana media pemebelajaran berbasis ICT. Penelitian ini menggunakan metode Class Action Research dalam rangka memperoleh hasil yang maksimal dari proses pembeuatan media pembelajaran yang dikembangkan mahasiswa dengan menggunakan tiga kali praktikum. software multimedia yang digunakan adalah camtasia studio.

Kata Kunci: Media pembelajaran, camtasi studio, video, pembelajaran ICT, bahasa Arab,

\section{PENDAHULUAN}

Keaberadaan serta posisi Bahasa Arab yang identik dengan bahasa agama Islam telah menjadikan bahasa Arab berkembang cukup pesat di Indonesia. Mata pelajaran bahasa Arab dapat ditemui di semua jenjang pendidikan baik sekolah yang berbasis agama, pondok pesantren dan madrasah bahkan sampai level perguruan. Perguruan Tinggi Keagamaan Islam. Mata kuliah bahasa Arab merupakan unsur penting dalam pembelajaan bahkan kurikulumnya mengarah 
kepada penyiapan tenaga guru agama yang memahami Agama Islam secara mendalam, disamping itu penggunaan literaturnyasebagian besar berbahasa Arab. Bahkan, pada sebagian besar Perguruan Tinggi Keagamaan Islam baik negeri maupun swasta tersebut memiliki program studi pendidikan Bahasa Arab yang secara khusus untuk menyiapkan mahasiswanya untuk menjadi guru bahasa Arab.

Universitas Islam Negeri Sunan Ampel Surabaya adalah salah salah universitas di Indonesia yang memberi perhatian besar dalam pembelajaran Bahasa Arab, hal ini terlihat dengan dikelolanya program studi Pendidikan Bahasa Arab (PBA) yang berada di Fakultas Tarbiyah dan Keguruan. tujuan utama didirikannya Program studi ini adalah untuk mencetak guru-guru bahasa Arab yang berkualitas dan siap mengajar bahasa Arab sesuai dengan tujuan pembelajaran yang telah ditentukan oleh sekolah atau madrasah.

Rusydi Ahmad Țu'aimah telah menjelaskan tentang tujuan pengajaran bahasa Arab bagi non-native speaker (penutur asing), yaitu: 1) Siswa harus mempraktekkan secara langsung bahasa Arab sesuai dengan yang dipraktekkan native speaker (penutur asli) bahasa ini; 2) Siswa harus mengetahui karakteristik bahasa Arab dan apa yang membedakannya dari bunyi kosakata, struktur, dan konsep bahasa lainnya; 3) Siswa harus mengenali budaya Arab dan mengetahui karakteristik orang Arab dan lingkungan di mana masyarakat berinteraksi dengan menggunakan bahasa Arab. ${ }^{1}$

Berdasarkan besarnya tujuan yang ingin dicapai dari pembelajaran bahasa Arab tersebut, maka sebagai pengajar bahasa Arab harus banyak melakukan pengajaran yang efektif, karena Indonesia juga merupakan non-native speaker yang mempunyai kesulitan tersendiri dalam mempelajari bahasa Arab, karena tujuan dari pembelajaran efektif adalah pengajaran yang memaksimalkan pembelajaran dengan cara tersingkat, sedikit usaha dan waktu dengan pencapaian pendidikan yang maksimal. ${ }^{2}$

Pembalajaran yang efektif dalam pengajaran bahasa Arab akan berjalan maksimal, dengan waktu yang relatif singkat dan tujuan pembelajaran bahasa Arab pun tercapai dengan maksimal. Salah satu cara yang digunakan oleh pengajar bahasa Arab untuk mencapai pembelajaran yang efektif tersebut yaitu dengan

1. Rusydi Ahmad Țu'aimah, Ta'lîm al-Lughah al-'Arabiyah lighairi al-Națiqîn bihâ: Manâhijuh wa Asâlibuh, Miṣr: Manshûrât al-Munaẓamah li Tarbiyah wa al-'Ulûm wa al-Thaqâfah Iisykû al-Ribâț, 1989, 49-50.

2. Muhammad 'Ali al-Khûlî. Asâlîb Tadrîs al-Lughah al-'Arabiyah, Al-Riyaḍ, 1986, 32. 
menggunakan media pembelajaran yang akan merangsang pembelajar bahasa Arab. Media pembelajaran adalah alat atau bentuk stimulus yang berfungsi untuk menyampaikan pesan pembelajaran. ${ }^{3}$ Maka, sebuah media pembelajaran akan menjadi perantara yang efektif, karena rangsangan yang didapat oleh pembelajar bahasa Arab akan mempermudahnya mempelajari bahasa Arab sehingga memotivasinya untuk belajar mandiri.

"Ajarilah anakmu sesuai zamannya", ungkapan tersebut membuat pengajar bahasa Arab dituntut untuk memberikan solusi atas permasalahan pengajaran bahasa Arab sesuai perkembangan keilmuwan yang selalu bergerak dinamis.

Sebagaimana diuraikan dalam Undang-Undang Nomor 14 Tahun tenatang kompetensi yang harus dimiliki oleh Guru dan Dosen, pada pasal 10 ayat (1) bahwa guru dan Dosen harus memliki kompetensi lebih khusus Guru yang meliputi kompetensi pedagogik, kompetensi kepribadian, kompetensi sosial, dan kompetensi profesional.

Dalam kontek pembelajaran bahasa Arab problem utamanya adalah adanya keinginan kuat yang sama antara guru dan siswa dalam mempelajari dan menguasai bahasa arab pada saat interaksi dalam proses bejalar mengajar. Karena pada proses belajar mengajar tidak boleh dengan sikap terpaksa mengikuti dan menyelesaikan jumlah dan struktur kurikulum yang telah dirancang. Karena proses belajar yang sebenarnya adalah ketika aspek fisik dan psikis manusia berkembang menjadi pribadi unggul yang efektif.

Oleh sebab itu, penggunaan teknologi yang terintegrasi dengan media pembelajaran akan dijadikan salah satu media yang akan mempermudah siswa dalam mempelajari bahasa Arab karena teknologi adalah media yang selalu berubah dan bergerak untuk meningkatkan kualitas pembelajaran. Selain itu, hampir semua siswa pun sudah sangat familiar dengan teknologi dalam kesehariannya. Hal inilah yang menjadikan media teknologi sebagai salah satu media yang akan diminati oleh siswa.

Salah satu teknologi yang digunakan untuk perkembangan media dalam pembalajaran bahasa Arab ini adalah video. Sebagaimana dikemukan leh Arsyad bahwa penggunaan video dalam pembelajaran merupakan penggunaan apalikasi

3.Rusman, Pembelajaran Berbasis Teknologi Informasi dan Komunikasi; Mengembangkan Profesionalitas Guru (Jakarta: Rajawali Press, 2013), 60. 
yang terdiri dari gambar gerak dan suara yang merupakan satu kesatuan yang dirangkai menjadi sebuah alur, serta terdapat pesan-pesan untuk ketercapaian tujuan pembelajaran yang bisa disimpan pada media pita atau disk. ${ }^{4}$

Jenis aplikasi pembuatan video yang digunakan dalam media pembelajaran bahasa Arab ini adalah aplikasi camtasia yang berbasis pada video tutorial. Camtasia adalah aplikasi perangkat lunak yang menyediakan fitur yang cukup kuat dan lengkap yang tujuan utamanya membuat, mengedit dan memproduksi video terbaik. Kemampuan camtasia dalam mengelola audio dan video menjadi salah satu aplikasi yang dapat mengembangkan media pembejaran yang kretif dan inovatif.$^{5}$

Bardasarkan uraian di atas, maka peneliti tertarik untuk mengambil penelitiannya dengan judul Peningkatan Kemampuan Membuat media Pembelajaran Bahasa Arab Menggunakan Aplikasi "Camtasia Studio" pada Mahasiswa Program Studi Pendidikan Bahasa Arab UIN Sunan Ampel Surabaya."

\section{METODE PENELITIAN}

Penelitian ini menggunakan jenis penelitian tindakan kelas (Classroom Action Research). Penggunaan metode ini, tujuannya adalah agar peneliti dapat melaksanakan proses penelitian sekaligus melakukan pengamatan secara langsung terhadap kejadian atau fenomena yang terjadi untuk mengetahui bentuk perubahan atas treatment yang diberikan oleh peneliti pada saat penelitian dilakukan. ${ }^{6}$ Oleh sebab itu, peneliti dapat memantau perubahan kondisi yang terjadi di dalam kelas sesuai dengan perbaikan-perbaikan yang sudah dilakukan di tiap siklus untuk mencapai tujuan.

Ciri-ciri darai Penelitian tindakan memiliki tiga ciri pokok, yaitu 1) Inkuiri reflektif, 2) kolaboratif, dan 3) reflektif. ${ }^{7}$

Pertama, inkuiri reflektif. Pada tahap ini peneliti mengacu pada permasalahan yang ada di dalam kelas sendiri yaitu sulitnya menemukan media

\footnotetext{
4 . Azhar Arsyad, Media Pembelajaran (Jakarta: Rajawali Press, 2013), 36.

5 . https://camtasia-studio.id.softonic.com/ diakses tanggal 10 Januari 2019.

6 . Deni Darmawan, Metode Penelitian Kuantitatif Cet. 3. (Bandung: Remaja Rosdakarya, 2013), 17.

7 .Iskandar Agung, Panduan Penelitian Tindakan Kelas bagi Guru (Jakarta: Bestari Buana Murni, 2012), 67.
} 
pembelajaran bahasa Arab yang diminati oleh siswa dan mudah dalam membuat media pembelajaran berbasis teknologi.

Kedua, Kolaboratif. Pada tahap ini, peneliti berusaha mewujudkan perbaikan atas kekurangan dari hasil penelitian, peneliti berkolaborasi dengan pengajar bahasa Arab dan media pembelajaran yang akan membantu peneliti untuk mengoreksi konten dari video yang sudah dibuat oleh mahasiswa.

Ketiga, reflektif. Pada tahap ini, peneliti memantau proses pembuatan media pembelajaran camtasia video, peneliti bukan hanya menilai hasil dari pembuatan media pembelajaran yang sudah dibuat oleh mahasiswa, tetapi juga proses ketika mahasiswa membuat media pembelajaran menggunakan aplikasi "camtasia". Proses pembuatan media yang berjalan lama ini membuat peneliti dapat melihat sejauh mana pemahaman mahasiswa akan materi yang telah disampaikan, atau sejauh mana kreatifitas mereka dalam melakukan editing atau dropping berbagai ikon, bentuk, teks dan lain sebagainya dalam aplikasi "camtasia".

Langkah-langkah peneliti dalam penelitian ini sesuai dengan mengacu pada langkah-langkah oleh Deborah Sout, yaitu 1) melakukan identifikasi pada focus penelitian, 2) melakukan pengumpulan data, 3) malakukan analisis dan Interpretasi data yang telah dikumpulkan, 4) menyusun rencana perbaikan, dan 5) Pelaksanaan sesuai siklus yang telah ditentukan. ${ }^{8}$

Pertama, Identifikasi bidang focus. Penelitian ini diawali oleh peneliti dengan mengidentifikasikan subjek-subjek apa saja yang ingin dipusatkan untuk penelitiannya. Dalam hal ini kesulitan mahasiswa dalam memilih dan menggunaplikasi media pebelajaran bahasa arab

Kedua, proses pengumpulan data. Dalam proses pengumpulan data, peneliti menghimpun dokumen-dokumen yang berhubungan dengan subjek-subjek yang yang telah difokuskan yang akan dicarikan solusinya .

Ketiga, analisis dan interpretasi data. Dari data yang sudah digali oleh peneliti di langkah sebelumnya, maka peneliti mulai menguraikan data tersebut, membandingkan, mengelompokkan, mengurutkan secara sistematis hingga

8. Nana Syaodih Sukmadinata, Metode Penelitian Pendidikan (Bandung: Remaja Rosdakarya, 2012), 146. 
keluarlah hasil analisis yang mampu diinterpretasikan oleh peneliti dengan lebih rinci.

Keempat, penyusunan rencana. Setelah analisis akan data mampu diinterpretasikan oleh peneliti, maka peneliti mulai merencanakan waktu pelaksanaan, aktivitas pembelajaran, sumber belajar dan lain sebagainya yang akan dilakukan dengan menggunakan camtasia video.

Kelima, pelaksanaan. Setelah dirancang sedemikian rupa, maka peneliti melaksanakan secara sesama dengan memanfaatkkan faktor-faktor pendukung yang menunjang pembelajaran. Selama proses pelaksanaan, peneliti melakukan evaluasi, monitoring dan pengumpulan data dengan berbagai teknik pengumpulan data yang didokumentasikan secara seksama dan lengkap yang dapat digunakan untuk menyempurnakan pelaksanaan kegiatan pembuatan media pembelajaan dengan mennggunakan aplikasi "camtasia".

\section{HASIL PENELITIAN}

\section{Identifikasi Bidang Fokus}

Melihat dari permasalahan yang ditemukan oleh peneliti, yaitu pembelajaran bahasa Arab yang terlalu monoton disebabkan pemakaian metode mengajar yang masih tradisional, maka diperlukan sebuah pembelajaran yang menggunakan sebuah metode yang sesuai dengan perkembangan zaman para peserta didik.

Peneliti memfokuskan pada penelitian yang berhubungan dengan media pembelajaran yang berbasis teknologi dan dekat dengan peserta didik yaitu pembelajaran melalui multimedia.

Konsep dasar Pembelajaran bahasa arab menggunakan multimedia, menurut Wina Sanjaya merupakan proses pembelajaran yang dipersiapan dan didesain menggunakan jenis media yang variatif berupa teks, gambar, film dan lain sebagainya dalam rangka mencapai tujuan pembelajaran yang dinginkan. ${ }^{9}$

9. Wina Sanjaya, Media Komunikasi Pembelajaran (Jakarta: Prenadamedia Group, 2016), 219. 


\section{Proses Pengumpulan Data}

Proses pengumpulan data, peneliti melakukan mengumpulkan data yang berasal dari mahasiswa tentang jenis-jenis multimedia yang familiar di antara mereka. Peneliti mengidentifikasi setiap jenis multimedia yang telah didapatkan kemudian menentukan kelebihan-kelebihannya.

\section{Analisis dan Interpretasi Data}

Setelah semua data telah didapatkan oleh peneliti, maka peneliti kemudian melakukan proses analisis dengan menyesuaikan jenis multimedia itu terhadap pembelajaran bahasa Arab.

Hasil analisis yang ditemukan oleh peneliti manyatakan bahwasannya:

Pertama, media video adalah media yang paling tepat untuk menarik perhatian siswa dalam pembelajaran bahasa Arab. Rusman memberikan beberapa kelebihan, yaitu: 1) pesan yang disampaikan dapat diterima lebih baik dan merata, 2) cocok untu menerangkan dan menguraikan sebuah proses, 3) meyelesaikan terbatasnya ruang dan waktu, 4) realistis, karena dapat digunakan sesuai dengan kebutuhan, 5) menimbulkan kesan yang mendalam yang mempengaruhi perubahan sikap dan prilaku siswa. ${ }^{10}$

Kedua, materi bahasa Arab yang diambil untuk dimasukkan dalam video yang digunakan tidak dibatasi. Artinya, mahasiswa diberi kebebasan dalam memilih materi bahasa Arab yang ingin dimasukkan dalam media pembelajarannya, dengan catatan agar disesuaikan dengan kompetensi yang telah ada buku siswa di sekolah.

Ketiga, Software multimedia yang digunakan dalam pembuatan media pembelajaran adalah Camtasia Studio Software atau perangkat lunak merupakan aplikasi media elektronik yang dikembangkan oleh TechSmith Coorporation. Penggunaan Software ini karena mudah digunakan merekam semua aktifitas secara langsung pada desktop dan screen computer langsung tanpa harus ada tambahan aplikasi lainnya. Selain itu, software ini juga dapat digunakan untuk memproduksi media pembelajaran dengan multimedia yang terintegrasi langsung

10 Rusman, dkk. Pembelajaran Berbasis Teknologi Informasi dan Komunikasi: Mengembangkan Profesionalitas Guru, Jakarta: Rajawali Press, 2013, 220. 
dengan e-learning karena memuat video tutorial atau pelatihan dan dapat digunakan video presentasi yang berbasis powerpoint.

\section{Penyusunan Rencana}

Di antara rencana yang disusun oleh peneliti adalah 1) Menyiapkan mahasiswa semester tiga yang akan dijadikan subjek penelitian dengan memberikan wawasan kepada mahasiswa tentang apa yang harus dilakukan mahasiswa diawal pembuatan camtasia video; 2) Merancang waktu pertemuan dan waktu praktikum. Peneliti di sini merancang waktu pertemuannya selama tiga kali, 3) Pembelajaran pun dirancang oleh peneliti dengan praktikum terbimbing.

\section{Pelaksanaan}

Pelaksanaan praktikum dilakukan tiga kali dengan menilai delapan materi selama masa praktikum, yaitu pembukaan video, callouts, zoom in part, audio, transition, crusor effect, voice narration, dan music background.

Kegiatan dari tiap materi yang diujikan adalah sebagai berikut: Pembukaan video, merupakan tampilan awal untuk memberikan informasi tentang identititas mata pelajaran, pembuat media, dan memuat lembaga atau intansinya. Callouts adalah fitur yang digunakan untuk membuat shapes atau teks yang informatif sebagai dasar untuk membuat animasi dengan berbagai macam icon yang menarik.

Zoom in part merupakan fitur yang digunakan membuat efek memperbesar maupun memperkecil gambar atau video. Fitur ini juga berguna membuat zoom in dan zoom out pada video yang diedit. Audio, fitur ini digunakan sebagai panel dalam menyetting audio / suara pada video serta digunakan untuk menyesuaikan audio dengan video yang diputar. Transition fitur ini digunakan untuk membiat tampilan yang menarik saat ada pergantian scene video dan juga untuk membuat animasi transisi antara 1 frame / bagian video ke frame selanjutnya. Crusor effect, fitur ini berguna memberikan effek terhadap crusor ketika proses Dubbing dan perpindahan dari satu slide ke slide yang lain. Voice naration digunakan untuk memasukkan suara (dubbing) dalam memberikan materi yang dibahas. Musik background adalah musik pengiring selama proses tutorial di sesusiakna dengan materi yang dibahasa.

Berikut ini akan ditampilkan dalam bentuk diagram tentang nilai-nilai mahasiswa dalam praktikum yang pertama, kedua, dan ketiga dengan menggunakan kedelapan materi di atas. 
Diagram 1: Hasil praktikum mahasiswa selama tiga kali pertemuan

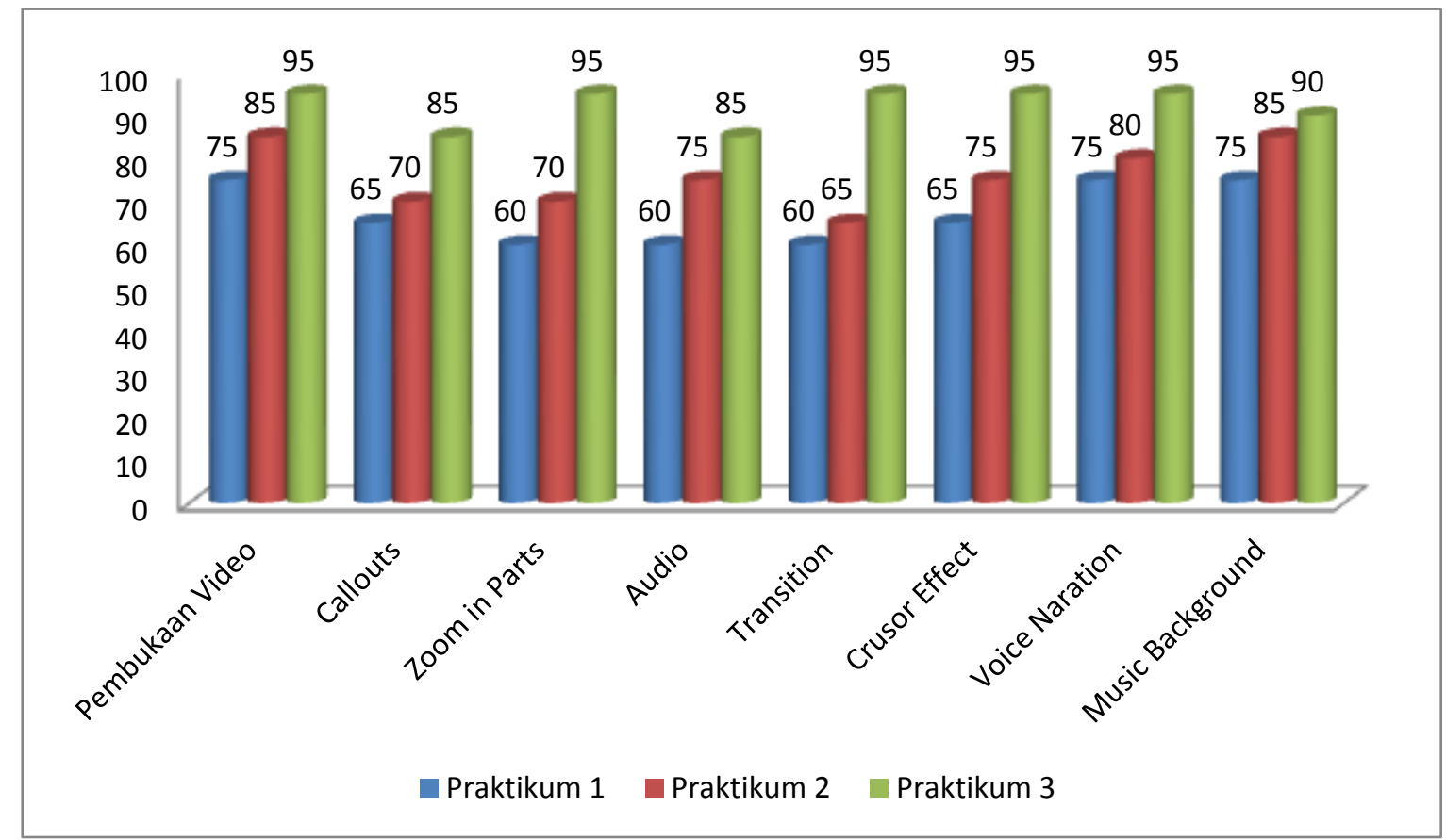

Pada praktikum pertama, terlihat dari diagram di atas dapat dilihat bahwa mahasiswa belum bisa memaksimalkan peran Callout, mengatur kesesuain musik pengiring dengan Voice naration, belum memasimalkan zoom in part, dan pada Audio belum ada editing. Namun dalam praktikum yang pertama ini mahasiswa sudah bisa menampilan video pembukaan dengan baik dan sudah mampu memilih music background yang sesuai.

Pada praktikum kedua, mahasiswa terlihat belum mampu menggunakan callout dengan baik meskipun terlihat ada peningkatan, transition yang disajikan juga masih terlalu cepat. Selain itu, masih perlu ada penyesuaian antara zoom in part dengan crussor efek. Peningkatan yang terlihat cukup siginifikan di sini ada pada pembukaan video yang dibuat mahasiswa sudah semakin menarik dan voice naration yang semakin bagus.

Pada praktikum ketiga, mahasiswa sudah mampu menggunakan callout yang sesuai dengan volume audio meskipun belum sempurna. Selain itu, crusor efek dengan materi sudah semain sesuai, voice naration pun sudah semakin bagus peningkatannya.

Dari ketiga kali praktikum di atas, maka peneliti menyimpulkan bahwa terjadinya peningkatan selama masa praktikum disebabkan adanya tantangan dalam diri mereka sendiri untuk membuat media pembelajaran bahasa Arab yang masih sangat minim jumlahnya. 
Rasa tertantang dengan mempelajari hal baru inilah yang membuat mahasiswa termotivasi sehingga semakin memperbaiki produk media pembelajaran bahasa Arab yang mereka buat. Sebagimana diungkapkan oleh Mc. Donald, bahwa motivasi merupakan perubahan energi positif yang terjadi pada diri seseorang yang ditandai dengan adanya "feeling" dimulai dengan adanya tanggapan positif terhadap adanya tujuan yang ingin dicapai. ${ }^{11}$ hal ini terlihat dari antusias dan hasil dari video yang cukup memuaskan.

Beriut ini adalah sebagian dari hasil video pemebelajaran bahasa Arab dengan camtasia video yang telah berhasil dibuat oleh mahasiswa.

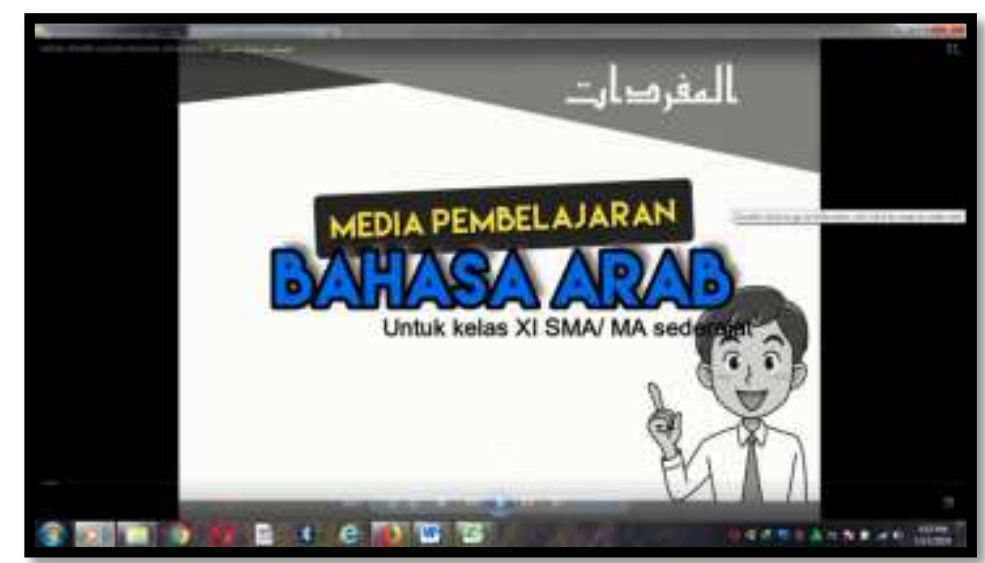

Gambar 1: Halaman depan hasil video mahasiswa

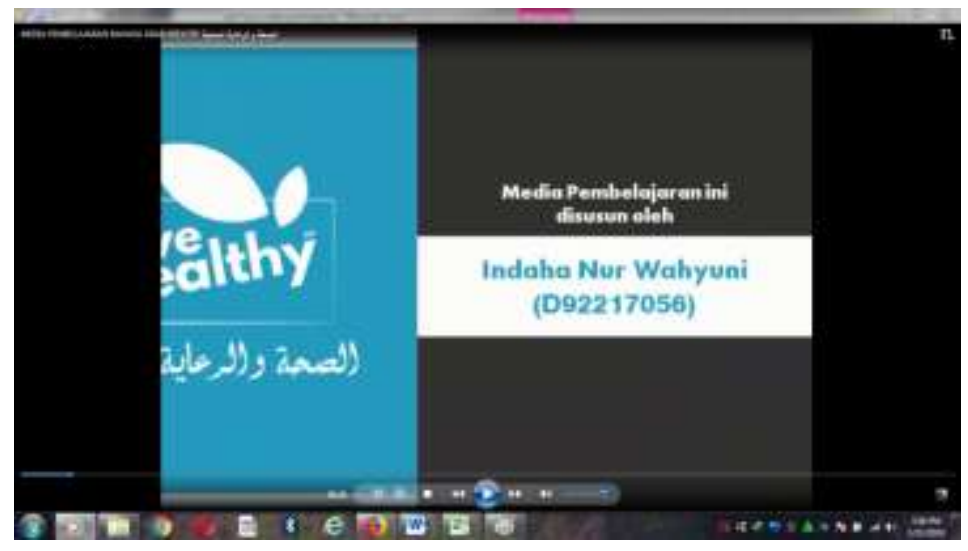

Gambar 2: Identitas mahasiswa

11. Sardiman, Interaksi dan Motivasi Belajar Mengajar, (Jakarta: Rajawali Pers, 2014), 73. 

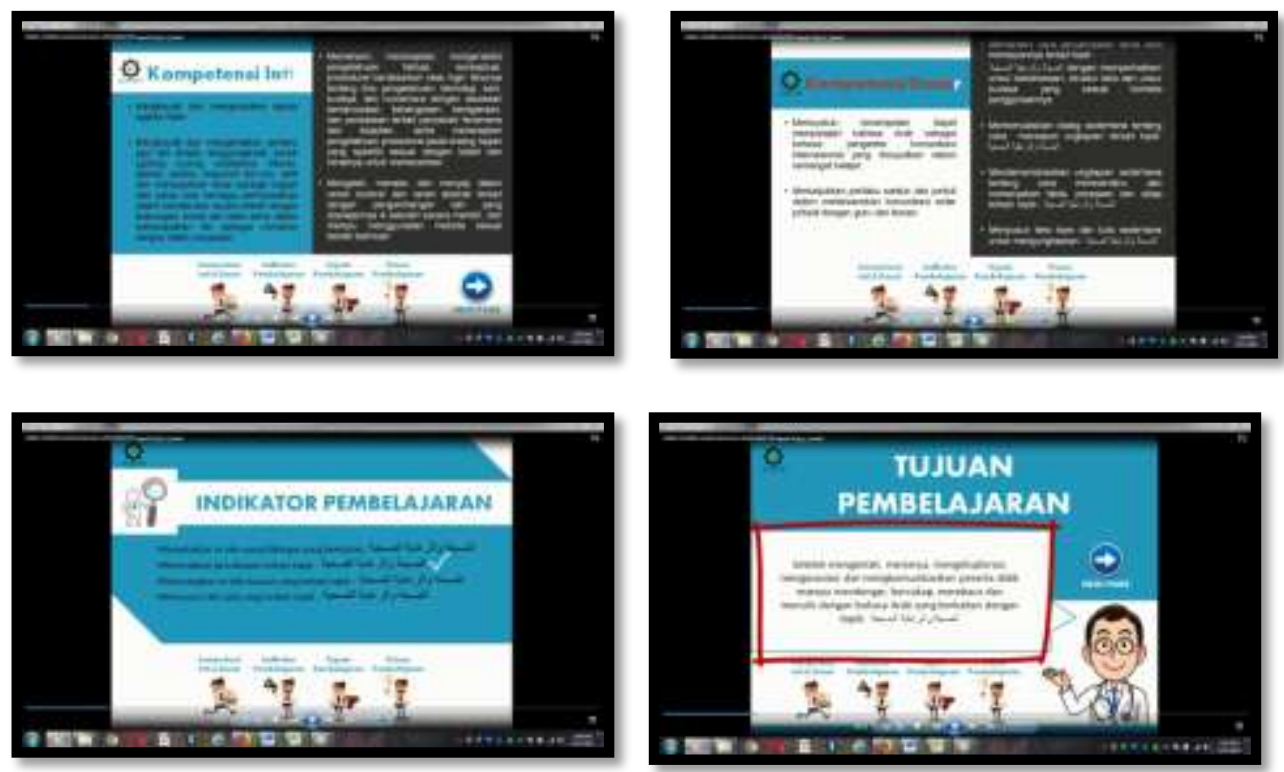

Gambar 3: Mahasiswa berkreasi dengan meletakkan kompetensi inti, kompetensi dasar, indicator pembelajaran, dan tujuan pembelajaran.

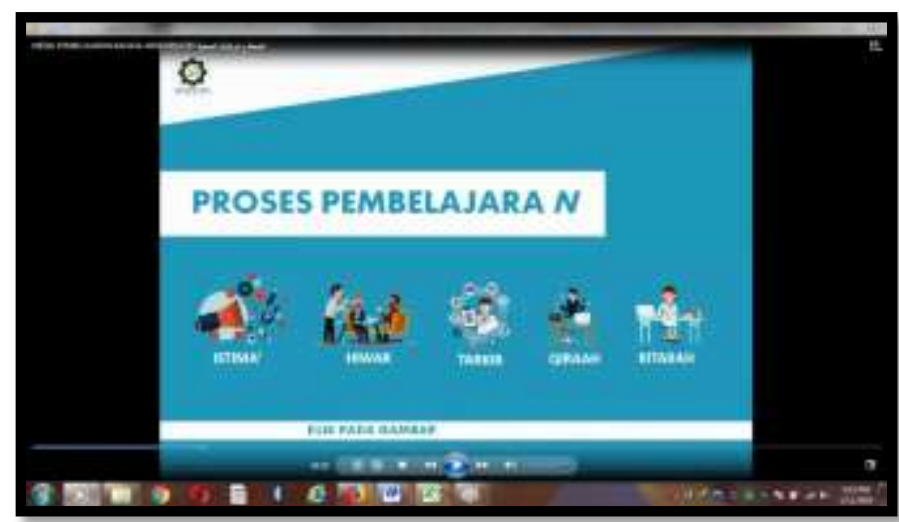

Gambar 4: Mahasiswa menjelaskan bahwa pembelajaran dalam video berisikan tentang Istima', hiwar, tarkib, qira'ah dan kitabah.

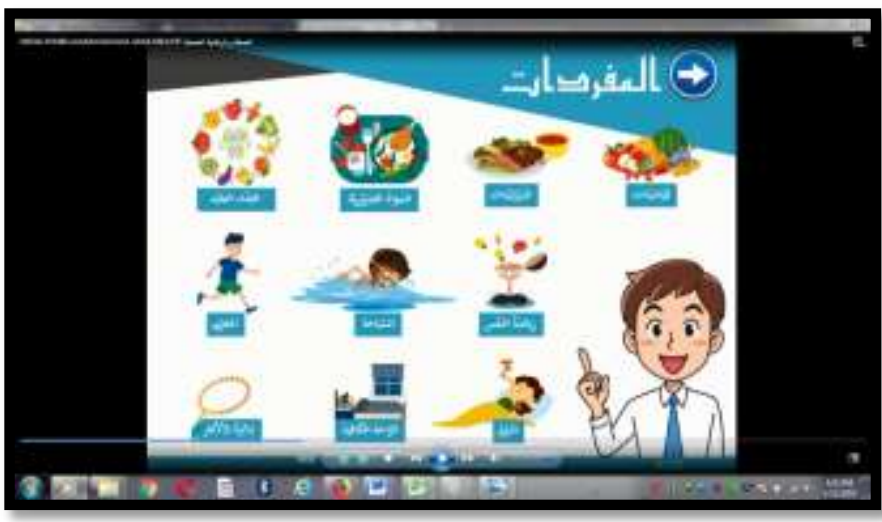

Gambar 5: Dalam materi istima' mahasiswa berkreasi dengan meletakkan gambar yang menarik minat siswa

Gambaran di atas merupakan beberapa cuplikan tentang camtasia video hasil dari kreatifitas mahasiswa, untuk video lengkapnya dapat dilihat di https://www.youtube.com/watch?v=dLfTe3Hy1Dg . 
Berdasarkan uraian tentang gambaran video tersebut, maka penggunaan video dalam pembelajaran sangat penting seperti dikatakan oleh Kemp and Dayton yang menyatakan bahwa media memiliki kontribusi yang sangat penting terhadap 1) tersmpainya pesan pembelajaran yang lebih berstandar; 2) pembelajaran lebih menarik; 3) pembelajaran menjadi lebih interaktif dan dengan melibatkan sekala aspek baik dari internal maupun eksternal. ${ }^{12}$

Materi bahasa Arab yang diambil dari video di atas adalah yang berhubungan dengan keempat skill dalam berbahasa dan ditambahi dengan tarkib. Namun seandainya mahasiswa ingin memberikan materi bahasa Arab yang lain pun tidak menjadi masalah, tergantung kreatifitas masing-masing mahasiswa.

Dalam video di atas, sangat terlihat bahwa mahasiswa dituntut untuk berkreasi secara mandiri untuk menciptakan sebuah media pembelajaran bahasa Arab yang bukan hanya menarik minat siswa, namun juga terdapat tutorial pembelajarannya, maka dengan adanya tutorial tersebut, seorang siswa yang hendak belajar mandiri dengan video tersebut akan memahami bagaimana tata cara penggunaan dan tujuan pembelajarannya.

Maka, dalam pembuatan media pembelajaran bahasa Arab dengan menggunakan camtasia video ini, mahasiswa dituntut menjadi seorang pribadi yang reatif.

Yatim Riyanto mengungkapkan beberapa ciri-ciri seorang individu yang kreatif, sebagai berikut: 1) Hasrat keingintahuan yang cukup besar; 2) bersikap terbuka terhadap pengalaman baru; 3) panjang/banyak akal.13 Dari ketiga ciri tersebut, sangatlah ada dalam video di atas, maka apabila mahasiswa telah menjadi seorang yang berjiwa reatif, ia akan mampu mengesplore camtasia video sehingga menghasilkan sebuah metode pembelajaran yang semakin bagus dan bermanfaat untuk peserta didik.

12. Wina Sanjaya, Perencanaan Sistem Pembelajaran, Cet. 7 (Jakarta: Prenadamedia Group, 2015), 210.

13 . Yatim Riyanto, Paradigma Baru Pembelajaran: Sebagai Referensi bagi Pendidik dalam Implementasi Pembelajaran yang Efektif dan Berkualitas, Cet ke-4. (Jakarta: Prenadamedia Group), $2014,226$. 


\section{PEMBAHASAN}

Camtasia Studio Software Camtasia berfungsi merekam aktifitas di komputer atau notebook yang sedang digunakan dalam format file video biasanya aplikasi ini digunakan untuk membuat tutorial video seperti microsoft office word, excel dan power point, dan lainnya.

Fungsi lain dari aplikasi camtasia adalah untuk mempermudah merekam aktivitas layar, mengeditnya (seperti menambahkan teks, sisip gambar, beri animasi atau transisi), menyimpannya ke disk, mengkonversi ke format video tertentu, atau mengubahnya menjadi Flash Video (FLV) untuk di-embed (dimasukkan) ke website seperti Youtube, Camtasia studio adalah software yang memiliki fitur-fitur dirancang untuk menghasilkan video yang berkualitas secara langsung dan juga dapat digunakan untuk mengedit video (Screen Recording \& Video Editing Software).

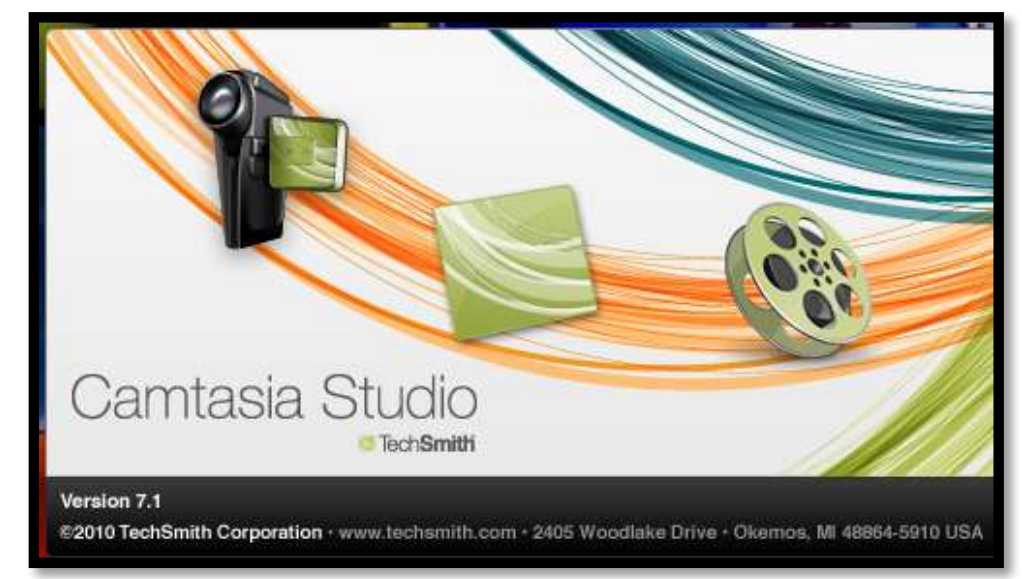

Gambar 6: halaman depan Camtasia studio versi 7.1

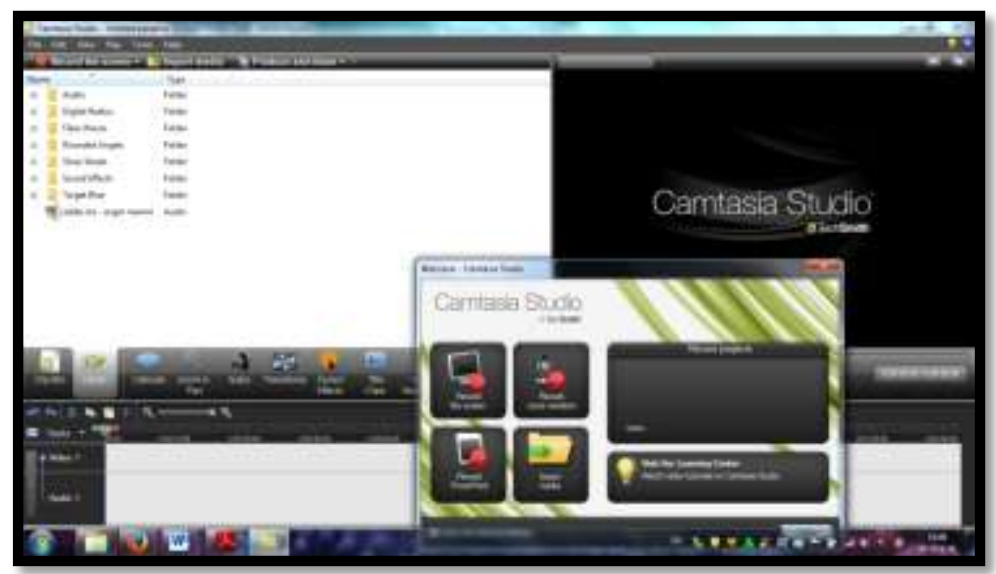

Gambar 7: Halaman depan dengan menu untuk memulai recording Camtasia studio versi 7.1 
Aplikasi Camtasia Studio berfungsi untuk menyimpan video dari hasil rekaman record screen dalam bentuk 3 tipe file setelah direndering yaitu diantaranya :

Pertama, dapat menyimpan file dalam bentuk vidio yang biasanya dikenal dengan type file dengan ekstention avi, mpg, mwp. Format tersebut memungkinkan bisa diputar pada media player atau Quick Time, sehingga dapat digunakan dengan mudah dan praktis.

Kedua, dapat menyimpan file dalam bentuk Macromedia Flash Player yang mempunyai type ekstention SWF. File type dijalankan dengan mengunakan Macromedia Flash Player.

Ketiga, dapat menyimpanan file dalam bentuk html. Type ini dapat melakukan browser ke internet sehingga dapat diakses oleh pengguna media pembelajaran interaktif.

Pada software ini terdapat empat navigasi utama, adapun navigasi utama adalah sebagai berikut: 1) Record the screen, berfungsi merekam aktivitas atau kegiatan pada desktop computer, 2) Import media berfungsi mengedit hasil rekaman yang sebelumnya telah direkam pada desktop computer atau memasukkan file yang lain, 3) Produce and share berfungsi untuk memproduksi hasil rekaman yang telah direcord serta diedit sebelumnya dan sebagai finishing dapat dibuat ke dalam bentuk CD, DVD, MPEG4, IPOD, IPON, atau menyimpan pada blog dan WEB

Ke tiga navigasi tersebut akan muncul setelah kita klik pertama kali seperti terlihata pada gambar di bawah ini:

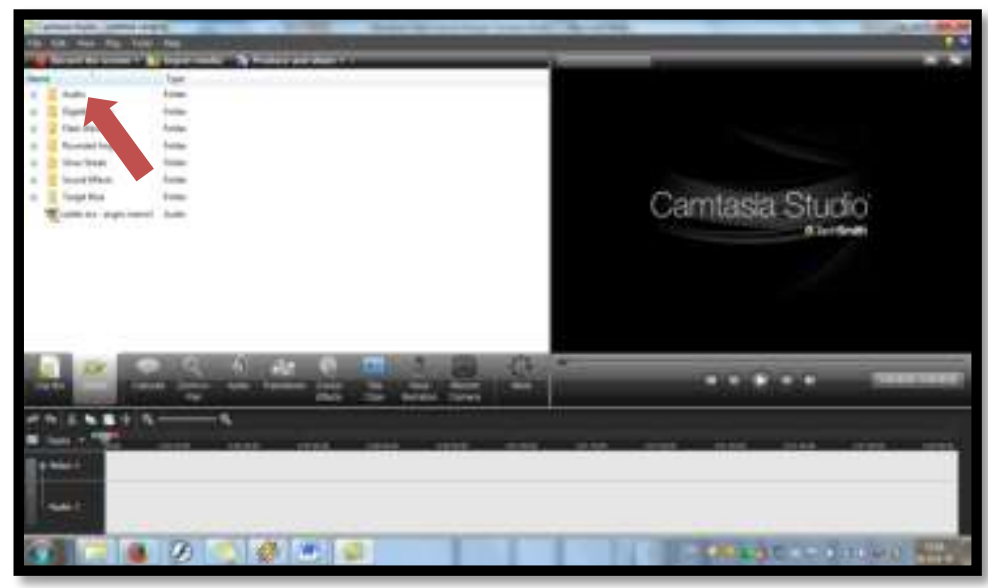

Gambar 8: Fasilitas Camtasia Studio versi 7.1 


\section{Cara menggunakan camtasia :}

\section{Pertama: Merekam dengan camtasia}

Satu: Klik ikon Camatasia studio 7, setelah itu akan akan muncul tampilan pada Gambar dibawah ini.

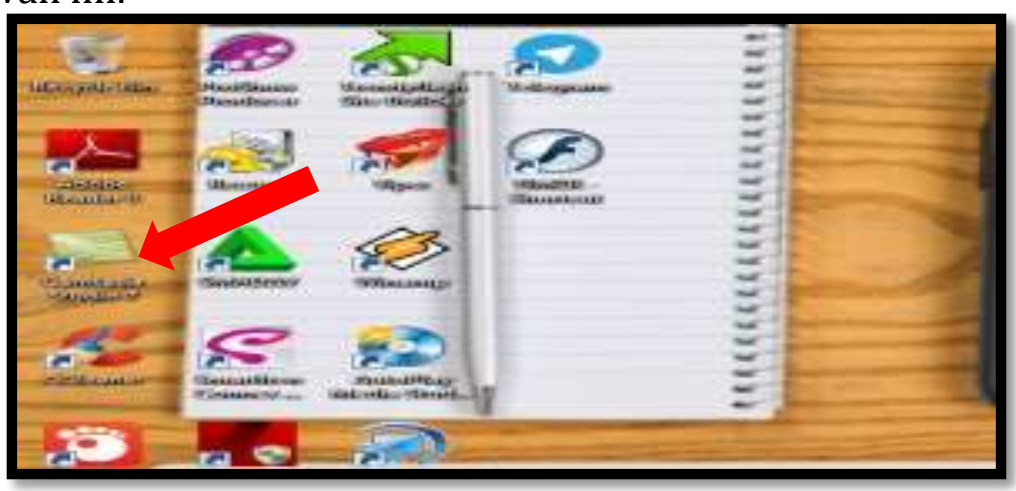

Gambar 9. Icon Camtasia Studio 7

Dua: Pilih menu Record the Screen lalu klik

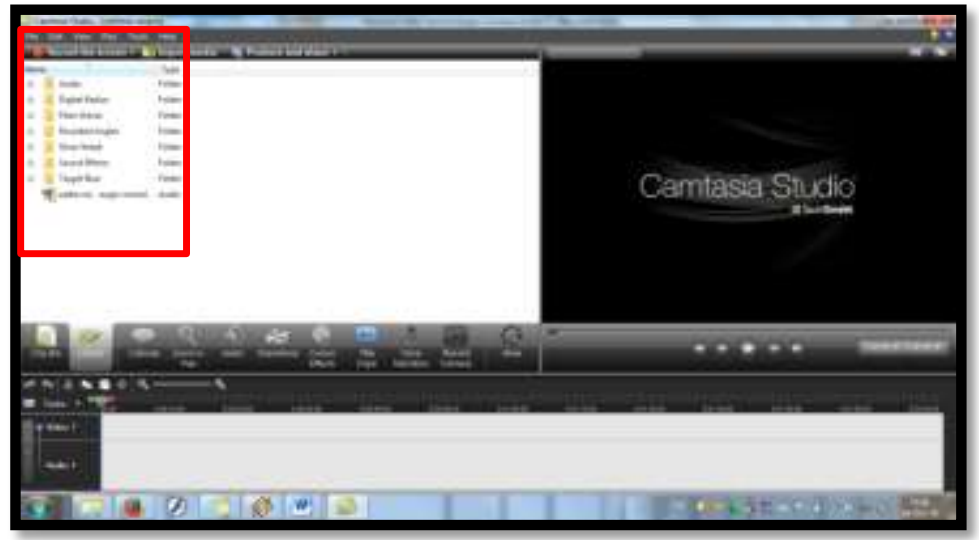

Gambar 10. Record the Screen Ccamtasia

Tiga: setelah proses klik selanjutnya akan muncul pilihan untuk mengatur ukuran vedio yang akan direkam, jika layar monitor secara penuh, maka klik Full screen, jika tidak, maka anda dapat mengatur pada bagian Custom atau langsung mendrag pada bagian area yang berwarna hijau sesuai keinginginan anda.

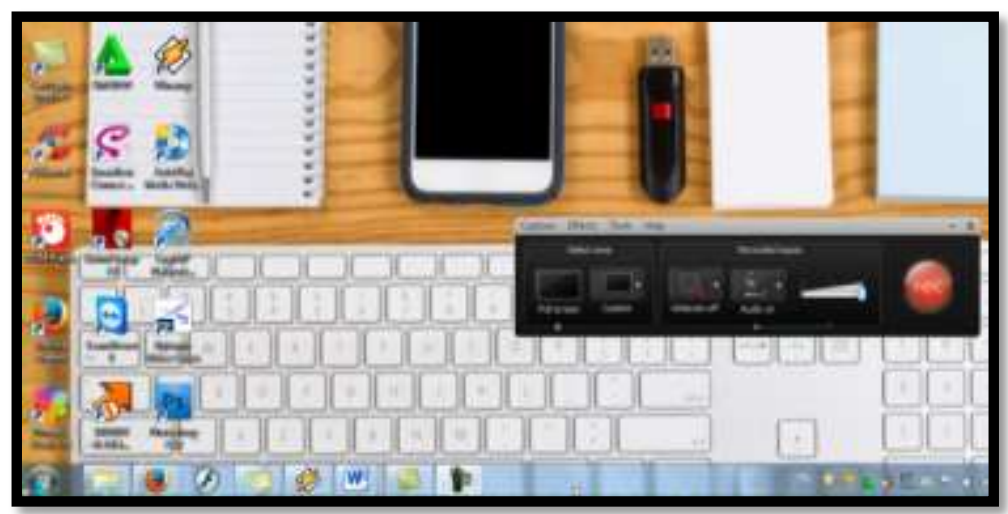

Gambar 12: Fitur rekaman Camtasia 
Empat: Jika ingin menampilkan pembuat tutorial, klik pada ikon webcam, perlu dipastikan terdapat video serta audio siap digunakan. Selanjutnya dapat memulai rekaman dengan mengklik tombol merah Rec.

Lima: pada layar akan muncul tampilan seperti berikut, warna hijau pada keempat pojok adalah daerah yang akan terekam pada video. Setelah selesai merekam, klik tombol stop.

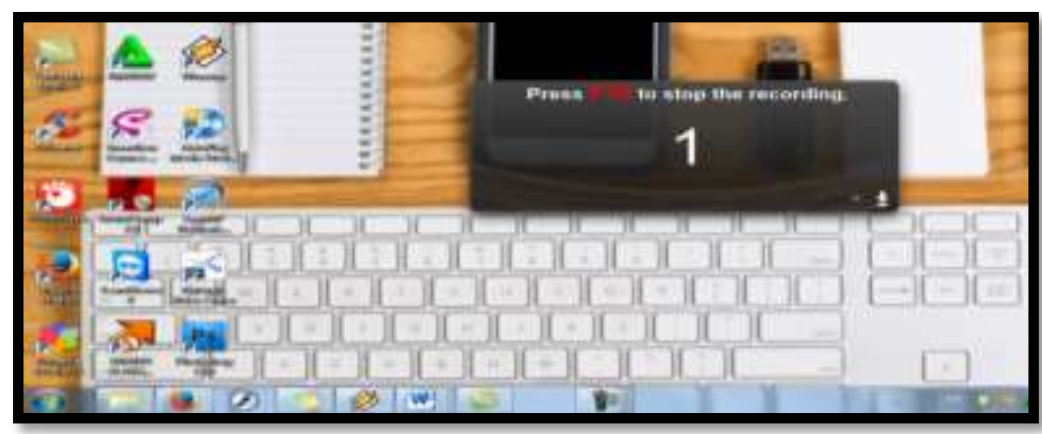

Gambar 13: Tampilan saat proses perekaman

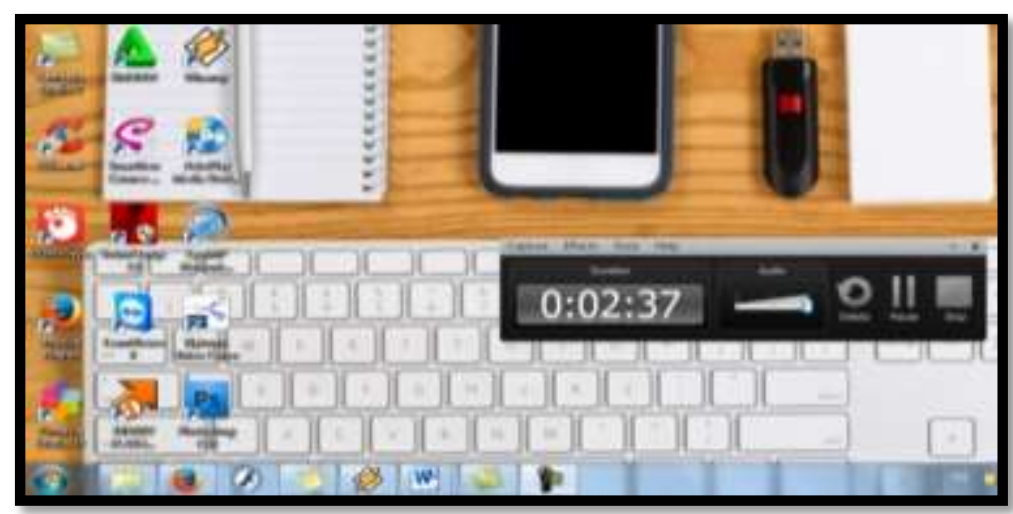

Gambar 14: Tampilan saat proses perekaman

Enam: Setelah melakukan rekaman akan muncul preview dari hasil rekaman yang telah dilakukan, jika selesai hasil rekaman langsung mengklik produce.

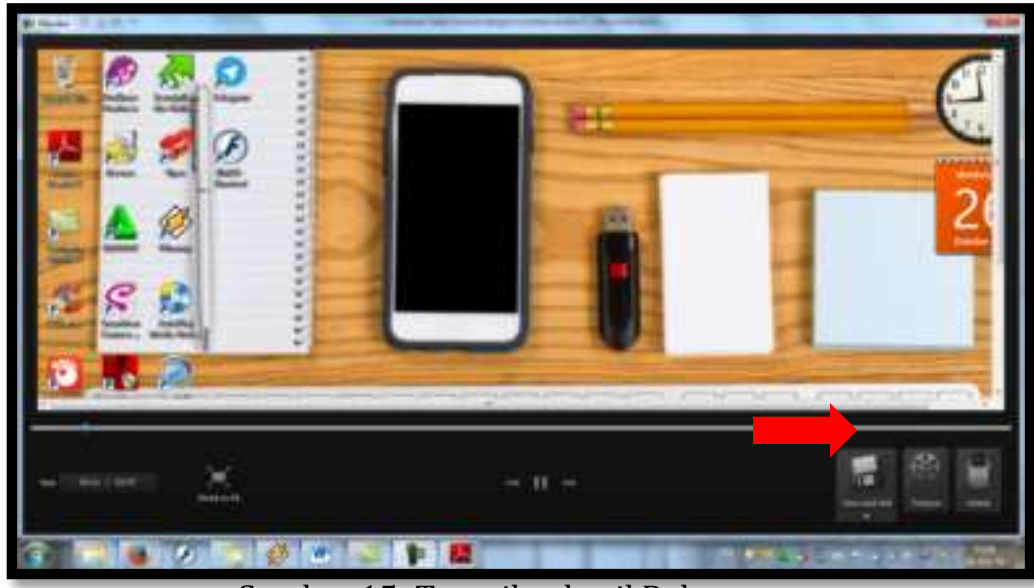

Gambar 15: Tampilan hasil Rekaman 
Tujuh: Jika ada ketidakpuasan pada saat merekam dapat dilakukan untuk mengedit terlebih dahulu sebelum memproduksi dengan mengklik fitur Save and edit selanjutnya akan muncul tampilan pada gambar

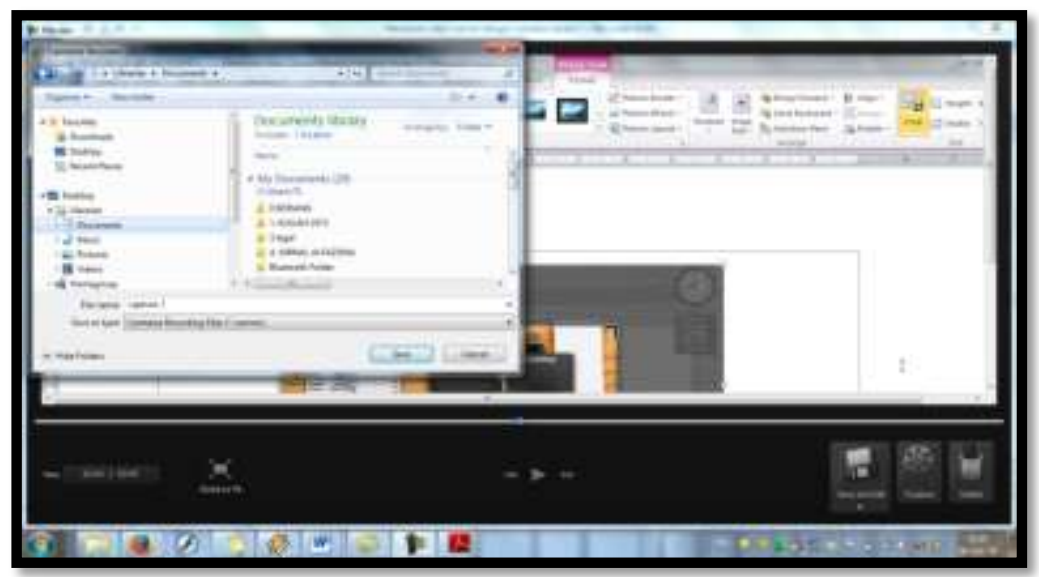

Gambar 16: Proses penyimpanan File Hasil rekaman

Delapan: Menyimpan hasil rekaman yang telah dilakukan, sebaiknya tentukan dulu nama file video yang baru direkam, kemudian lakukan Save.

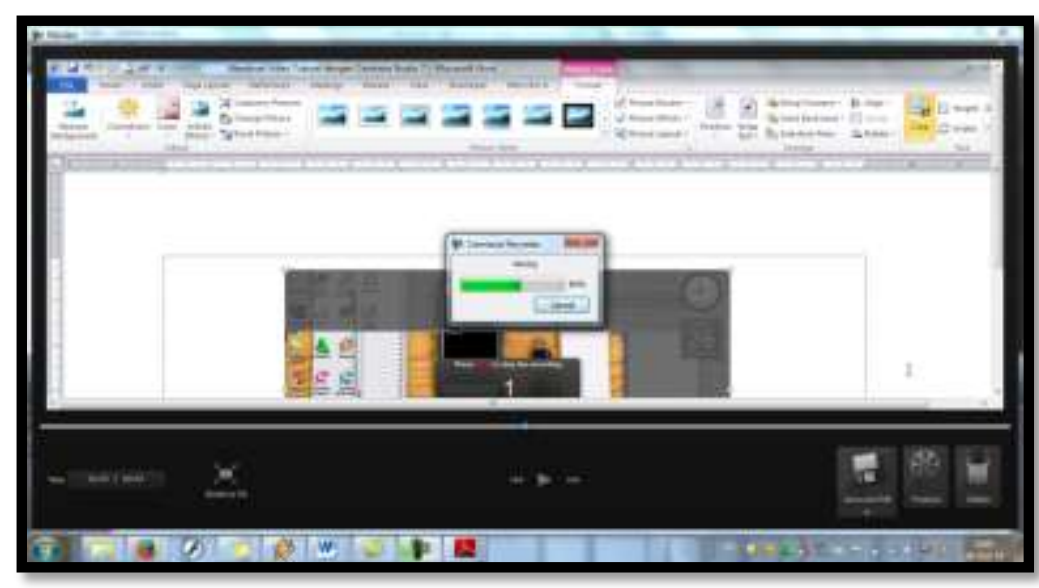

Gambar 17: hasil rekaman kita buka file yang telah kita simpan di file

\section{Kedua: Proses Editing video}

Pada aplikasi Camtasia Studio 7, kegiatan proses editing merupakan bagian penting untuk mengelola tampilan video agar lebih manarik, dengan cara menentukan ukuran video terlebih dahulu, dapat mencoba beberapa ukuran yang disarankan seperti 640x384. 
Satu: Tampilan editing

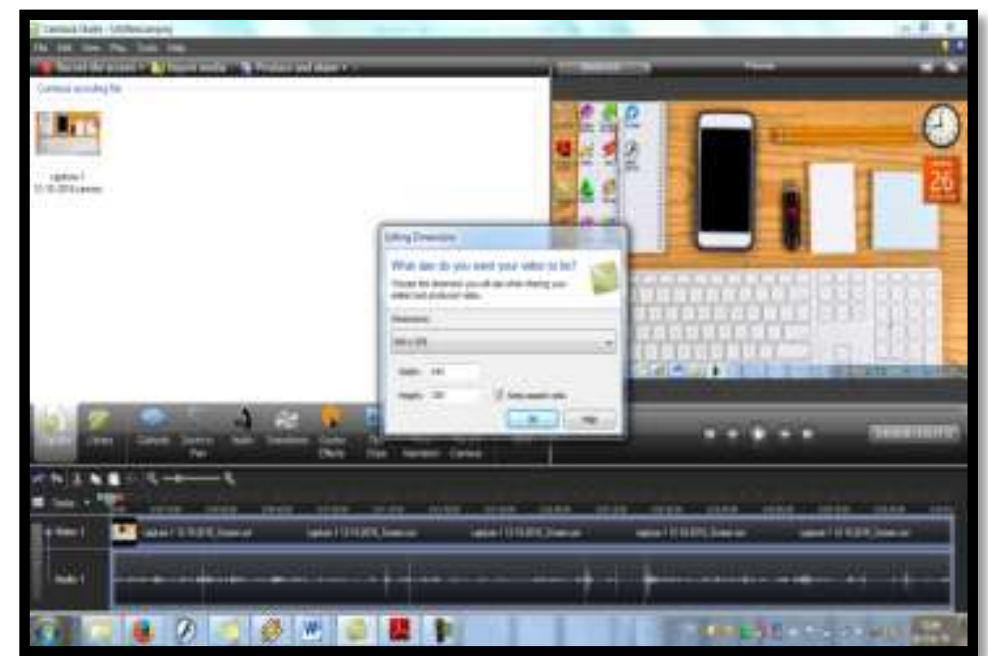

Gambar 18: Tampilan awal editing

Dua: Memilih ukuran video

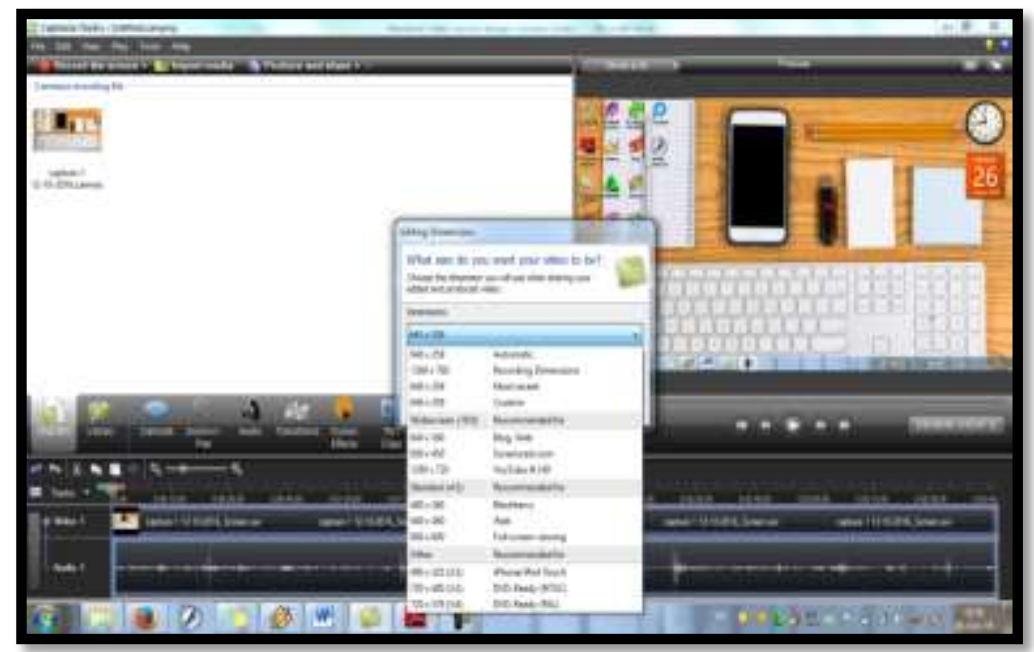

Gambar 19: Tampilan memilih bentu ukuran video

Tiga: Fasilitas editing

Fasilitas editing pada camtasia seperti pada gambar di beriut ini :

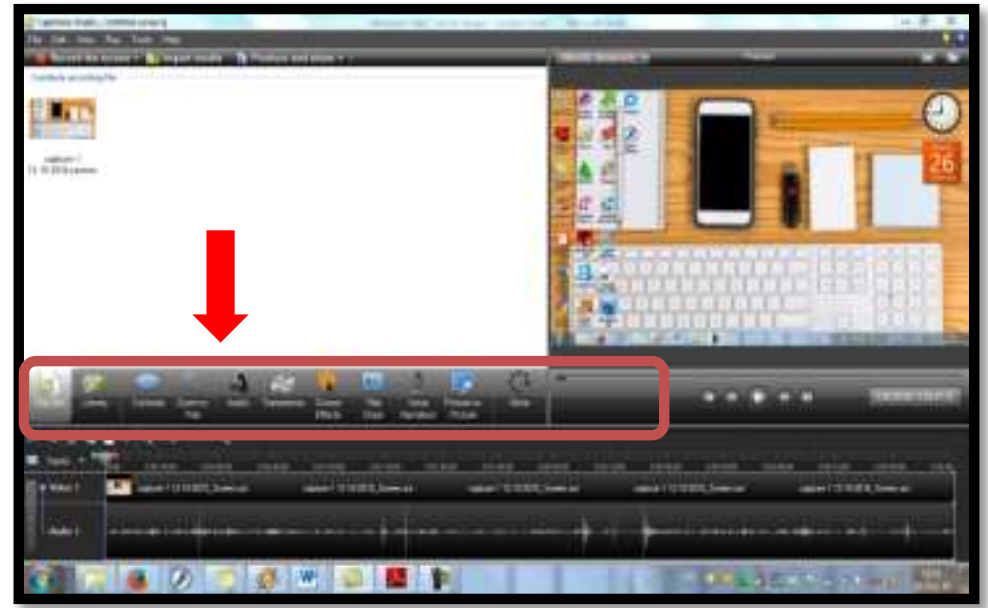

Gambar 20: Fasilitas editing dalam camtasia 
Fasilitas tersebut adalah, 1) Clip bin : merupakan tempat yang menyimpan file hasil rekaman kita, 2) Library : merupakan fasilitas untuk audio dan gambar untuk mendukung proses editing, 3) Callout: merupakan shaves untuk membuat tuliasan yang variatif dalam editing video. 4) Audio; meruakan vasilitas yang nanti membantuk mengedit suara yang berisi fade in dan fade out dan silence audio, 5) Transition: merupakan efek perpindahan dari sati clip dari clip yang lain, 6) Crusor effect: merupakan vasilitas memberikan efek pada crusor pada saat proese editing, 7) Title clip: memberikan tulisan pada clip yang berjalan. 8) Voice Naration: merupakan alat untuk memberikas suara narasi pada clip Untuk menambah suara pada video atau menghilangkan suara dan mengganti dengan suara lain dubbing. 9) Picture in picture: merupakan fitur untuk menambahkan gambar pada clip yang berjalan. 10) Cutting ikon bergambar gunting untuk memotong bagian yang tidak dikehendaki pada track video. Penggunaanya crusor arahkan track posisikan ikon pada bagian awal video yang akan digunting. Selanjutnya kemudian klik ikon, maka video itu telah terbagi dua. Geser lagi ke bagian akhir video yang akan dipotong kemudian klik ikon

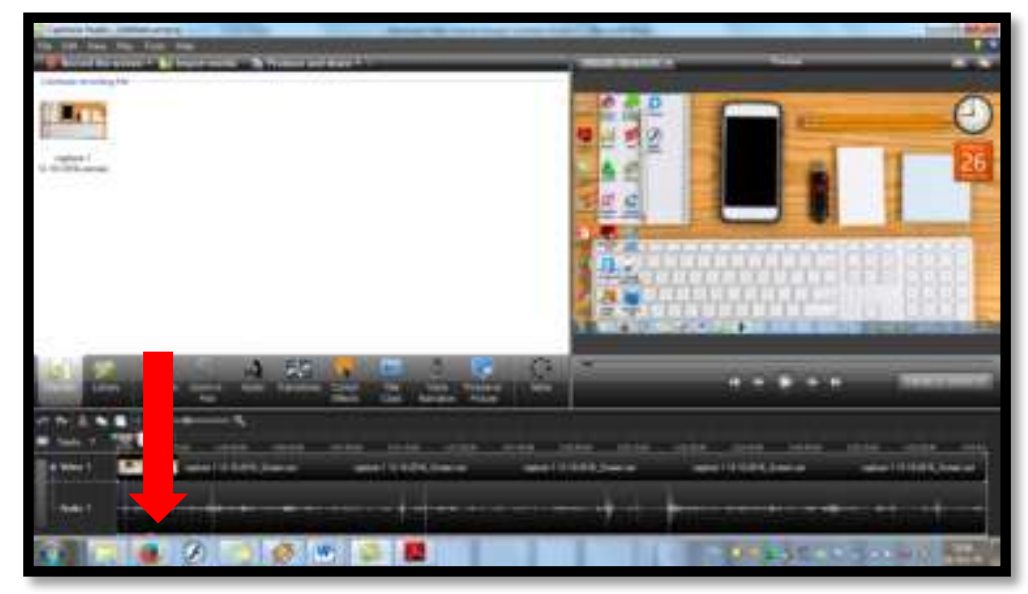

Gambar 21: Cara membagi video (split)

Setelah video telah terbagi tiga, arahkan cursor dengan meng klik pada bagian yang akan digunting, maka bagian yang berwarna biru kemudian klik Delete atau untuk menghilangkan bagian dari video tersebut .

\section{Ketiga: Menyimpan hasil editing menjadi Video}

Ketika selesai melakukan proses edit video, selanjutnya dapat disimpan dengan cara klik save project, maka file akan tersimpan sebagai file camtasia studio project atau *.camproj. jika video hasil edit finish dapat dilakukan melalui proses randerring. 
Satu: Pilih menu produce and share. klik

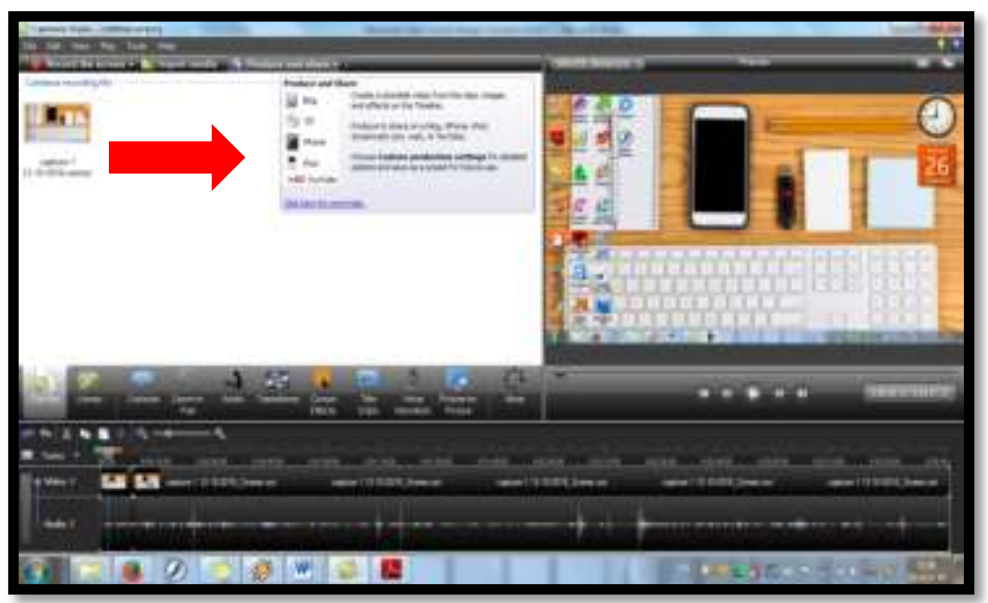

Gambar 22: menu produce and share

Dua: Pilih jenis hasil produksi video yang diinginkan, kalau memilih web karena produksi lainnya bisa di setting. pilih costume production setting kemudian klik next .

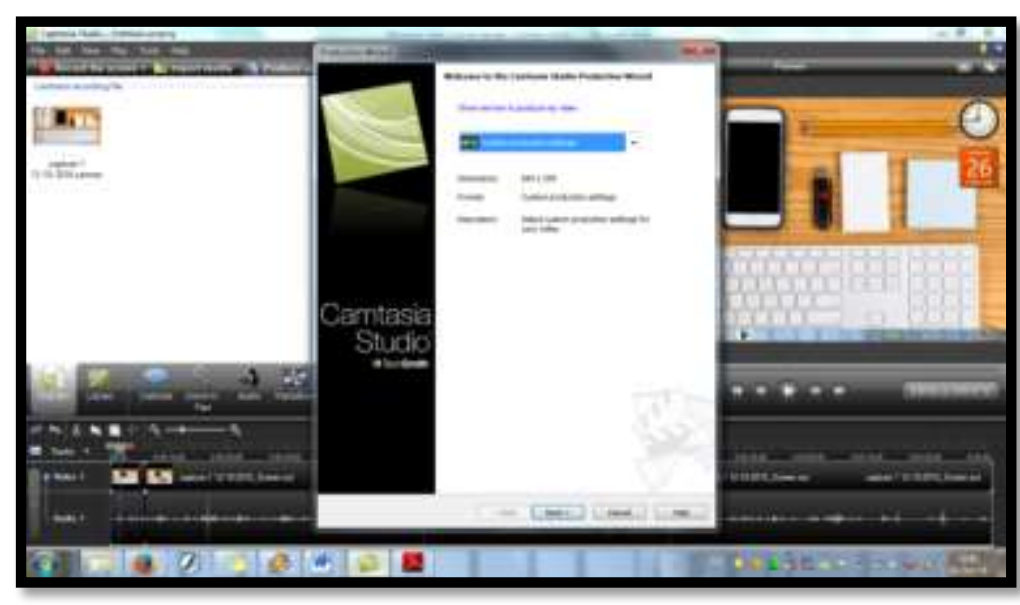

Gambar 23: Tampilan Format file produce 
Tiga: Pilih format Avi klik next

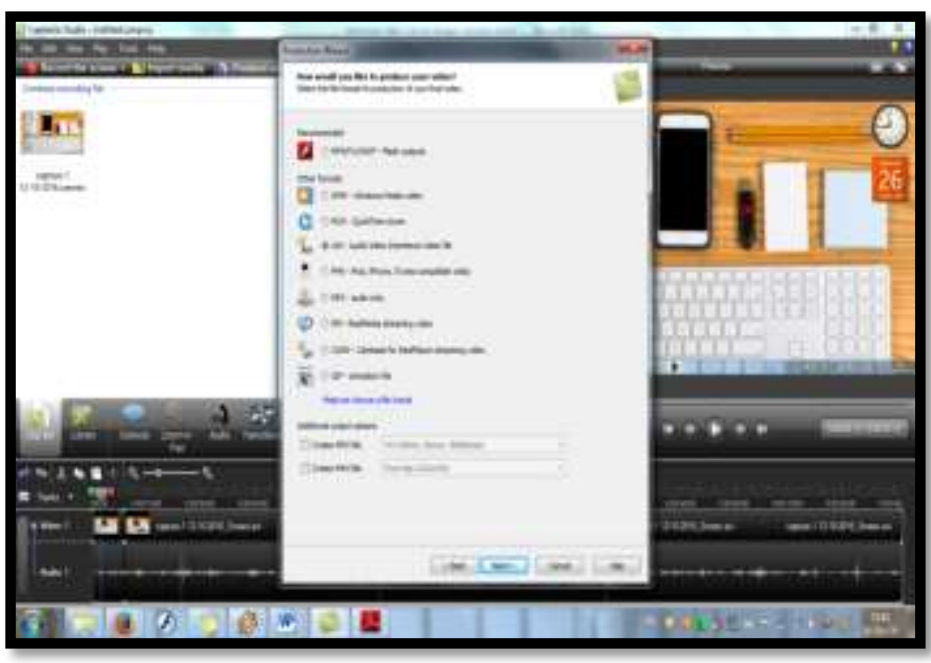

Gambar 24: menu Format file produce

Empat: Menulis nama file klik finish

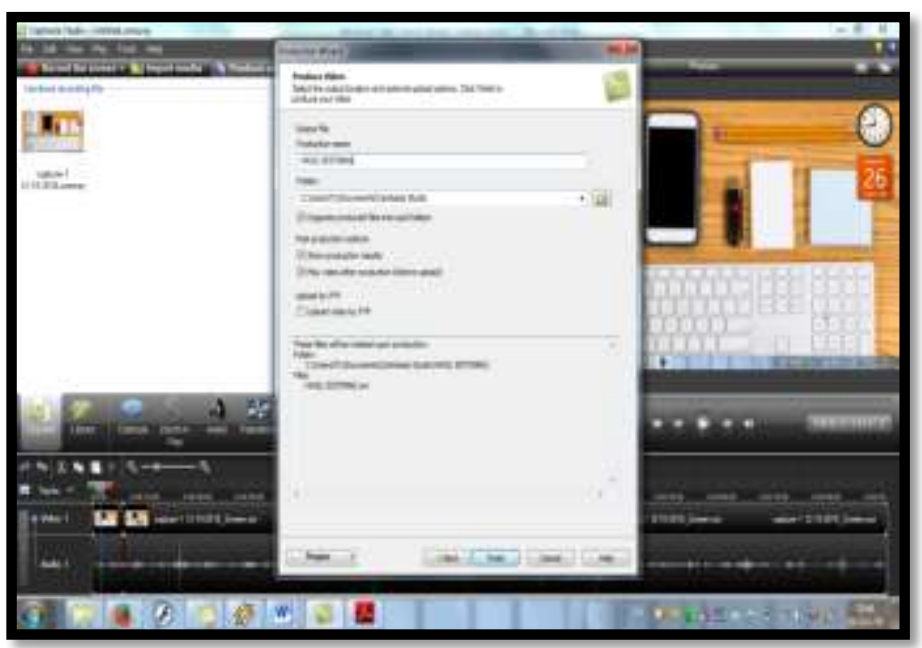

Gambar 25: Menulis nama file video

Lima: Rendering video

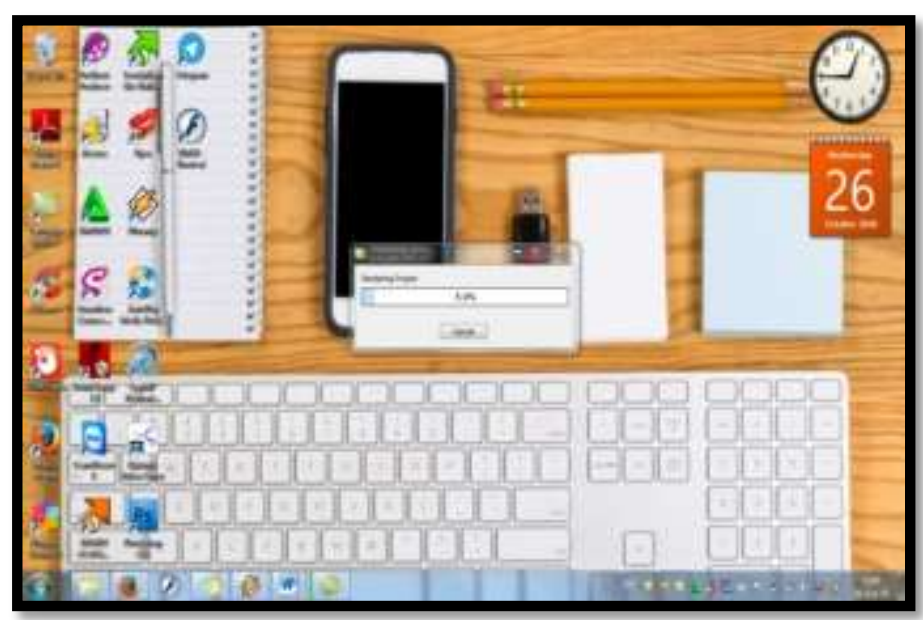

Gambar 26: Proses rendering Video 
Enam: Prosse selasai

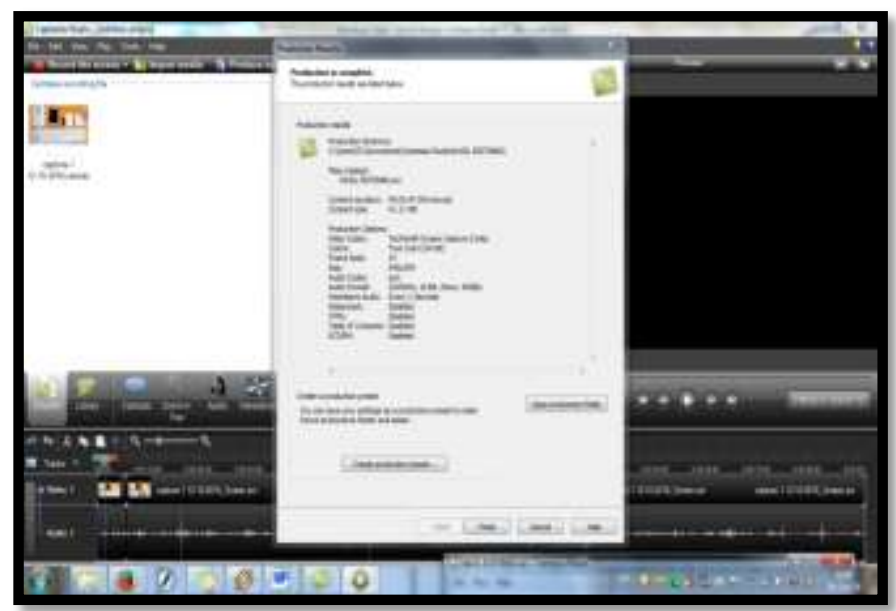

Gambar 27: Proses Rendering Selesai

\section{KESIMPULAN}

Camtasia Studio Software (perangkat lunak) merupakan aplikasi media elektronik yang memiliki banyak manfaat, di antaranya adalah mempermudah untuk merekam aktivitas layar, mengeditnya (seperti menambahkan teks, sisip gambar, beri animasi atau transisi), menyimpannya ke disk, mengkonversi ke format video tertentu, atau mengubahnya menjadi Flash Video (FLV) untuk diembed (dimasukkan) ke website seperti Youtube, dan lain sebagainya.

Hasil dari penelitian ini menunjukkan bahwa dengan dibuatnya media pembelajaran bahasa Arab dengan menggunakan camtasia video maka 1) peserta didik yang akan memanfaatkannya dapat berinteraksi langsung dengan bahan ajar walau tanpa kehadiran guru atau buku di sana; 2) peserta didik dapat mengulangulang video sehingga mereka dapat belajar sesuai dengan kemampuannya; 3) penggunaan media pembelajaran dengan camtasia video lebih menarik minat peserta didik dan memotivasi mereka dalam belajar, karena generasi milenial saat ini adalah generasi yang tidak bisa lepas dengan teknologi; 3) peserta didik dapat melakukan perbandingan keilmuwan bahasa Arab secara mandiri dengan bukubuku yang lain yang di abaca sehingga meningkatkan sikap kritis peserta didik; 4) mahasiswa dapat mengkreasikan bahan ajar yang ingin dimasukkannya ke dalam video sesuai dengan kesulitan yang dilihat di lapangan; 4) peserta didik. 


\section{DAFTAR PUSTAKA}

Agung, Iskandar. Panduan Penelitian Tindakan Kelas bagi Guru, Jakarta: Bestari Buana Murni, 2012.

al-Khûlî, Muhammad 'Ali. Asâlîb Tadrîs al-Lughah al-'Arabiyah, Al-Riyaḍ, 1986.

Arsyad, Azhar. Media Pembelajaran, Jakarta: Rajawali Press, 2013.

Aziz Fahrurrozi, "Pembelajaran Bahasa Arab : Problematika dan Solusinya" ARABIYAT: Jurnal Pendidikan Bahasa Arab dan Kebahasaaraban [Online], Vol. 1 No. 2 December 2014 DOI: https://doi.org/10.15408/a.v1i2.1137

Hamid, M. Abdul Pembelajaran bahasa Arab: Pendekatan, metode, strategi, materi, dan media. UIN-Maliki Press, Malang. 2008

Rosyidi, Abdul Wahab and Ni'mah, Mamlu'atul, Memahami konsep dasar pembelajaran bahasa arab. UIN-Maliki Press, Malang. ISBN 978-602-958409-7, 2011

Zainiyati, Husniyatus Salamah, Pengembangan Media Pembelajaran Agama Islam Berbasis ICT, Kencana, Jakarta 2017

Darmawan, Deni. Metode Penelitian Kuantitatif, Cet. 3. Bandung: Remaja Rosdakarya, 2013.

Riyanto, Yatim. Paradigma Baru Pembelajaran: Sebagai Referensi bagi Pendidik dalam Implementasi Pembelajaran yang Efektif dan Berkualitas,Cet ke-4. Jakarta: Prenadamedia Group, 2014.

Rusman, dkk. Pembelajaran Berbasis Teknologi Informasi dan Komunikasi: Mengembangkan Profesionalitas Guru, Jakarta: Rajawali Press, 2013.

Sanjaya, Wina. Media Komunikasi Pembelajaran, Jakarta: Prenadamedia Group, 2016.

Sanjaya, Wina. Perencanaan Sistem Pembelajaran, Cet. 7 Jakarta: Prenadamedia Group, 2015.

Sardiman, Interaksi dan Motivasi Belajar Mengajar, Jakarta: Rajawali Pers, 2014.

Sukmadinata, Nana Syaodih. Metode Penelitian Pendidikan, Bandung: Remaja Rosdakarya, 2012.

Wina Sanjaya, Media Komunikasi Pembelajaran, Jakarta: Prenadamedia Group, 2016.

Țu'aimah, Rusydi Ahmad. Ta'lîm al-Lughah al-'Arabiyah lighairi al-Națiqîn bihâ: Manâhijuh wa Asâlibuh, Mișr: Manshûrât al-Munaẓamah li Tarbiyah wa al-'Ulûm wa al-Thaqâfah Iisykû al-Ribât, 1989, 49-50. 
al-Khûlî, Muhammad 'Ali. Asâlîb Tadrîs al-Lughah al-'Arabiyah, Al-Riyaḍ, 1986. https://camtasia-studio.id.softonic.com/, diakses tanggal 10 Januari 2019. http://eprints.unsri.ac.id/670/1/Video_Pembelajaran_dengan_Camtasia.pdf https://ayobelajarmultimedia.wordpress.com/home-3/camtasia-studio-6-0/ http://proyektik.blogspot.co.id/2014/11/camtasia-studio-aplikasi-edit-video.html https://www.youtube.com/watch?v=dLfTe3Hy1Dg . 